\title{
PASTURE TOLERANCE TO THE HERBICIDE METSULFURON-METHYL
}

\author{
T.K. JAMES ${ }^{1}$, A. RAHMAN ${ }^{1}$ \\ and M.J. CORNWELL ${ }^{2}$ \\ ${ }^{1}$ AgResearch, Ruakura Research Centre, Private Bag 3123, Hamilton \\ ${ }^{2}$ Du Pont (New Zealand) Ltd, Private Bag 97641, Manukau City
}

\begin{abstract}
Trials were carried out in spring and autumn at two locations in New Zealand to measure the effects of metsulfuron-methyl on pasture production and composition. Metsulfuron-methyl at 3-12 g/ha resulted in $20-45 \%$ loss of herbage production. This was particularly evident for two months after spraying, with no significant reduction in dry matter yield 3 months after treatment in spring. The effect on pasture composition was more persistent. Metsulfuron-methyl, along with clopyralid and picloram $+2,4$-D completely removed the clover for the three month duration of the trial. The consequences of broadcast application of these herbicides in pasture need to be considered in the context of the overall farming system.
\end{abstract}

Keywords: metsulfuron-methyl, tribenuron, clopyralid, picloram+ 2,4-D, pasture tolerance.

\section{INTRODUCTION}

The problem of difficult to control and herbicide resistant weeds in pasture has resulted in management problems on many New Zealand farms (Martin et al. 1986; Harrington and Popay 1987). In response to this situation, 2,4-D + picloram and clopyralid have recently been registered for broadcast application to pastures. Both these herbicides damage pasture plants (James et al. 1995) but farmers are willing to accept this risk in gaining control of problem weeds. The herbicide metsulfuronmethyl has high efficacy on many of these weeds (Rahman et al. 1994; James et al. 1997), but is currently recommended only for spot application in pasture to limit pasture damage. Previous studies of the metsulfuron-methyl damage to pasture have evaluated the high rates used for control of brush weeds (Popay et al. 1985). However, anecdotal evidence from farmers and Plant Pest Officers suggested that lower rates of metsulfuron-methyl were being used as broadcast applications to control both phenoxyresistant nodding thistle (Carduus nutans) and multicrown ragwort (Senecio jacobaea). The aim of the work reported in this paper was to evaluate the effects of lower rates of metsulfuron-methyl, on pasture production and composition compared to those of clopyralid and 2,4-D + picloram. Tribenuron was also evaluated in combination with low rates of metsulfuron-methyl as it may increase the spectrum of weeds controlled and causes less pasture damage (Rahman et al. 1993).

\section{MATERIALS AND METHODS}

Two trials were carried out in each of the North and South islands, viz. at Hamilton in Waikato and Balclutha in Otago. The trials were conducted in spring and autumn and details of the sites and treatment dates are presented in Table 1. All trials were established on typical perennial ryegrass (Lolium perenne)/white clover (Trifolium repens) swards.

The herbicide treatments (Table 2) were applied with small plot sprayers in 200300 litres/ha water at 200-220 kPa. Individual plots were at least $10 \mathrm{~m}$ x $2 \mathrm{~m}$ and treatments were replicated four times in randomised complete block layouts. 
TABLE 1: Details of the four metsulfuron-methyl pasture tolerance trials.

\begin{tabular}{|c|c|c|}
\hline Details & Hamilton site & Balclutha site \\
\hline Soil type & Horotiu sandy loam & Tokomariro yellow grey earth \\
\hline Organic carbon $(\%)$ & 5.4 & 3.8 \\
\hline $\mathrm{pH}$ & 5.2 & 5.8 \\
\hline $\begin{array}{l}\text { Application date } \\
\text { Weather } \\
\text { Temperature }\left({ }^{\circ} \mathrm{C}\right) \\
\text { Pasture height }(\mathrm{cm})\end{array}$ & $\begin{array}{ll} & \text { Spring trials } \\
9.10 .97 & \\
\text { overcast } & \\
15 & \\
5-10 & \end{array}$ & $\begin{array}{l}30.9 .97 \\
\text { overcast } \\
11 \\
3-5\end{array}$ \\
\hline \multicolumn{3}{|c|}{ Autumn trials } \\
\hline Application date & 7.4 .98 & 13.3 .98 \\
\hline Weather & $75 \%$ cloud & sunny \\
\hline Temperature $\left({ }^{\circ} \mathrm{C}\right)$ & 14 & 16 \\
\hline Pasture height (cm) & $6-8$ & up to 20 \\
\hline
\end{tabular}

TABLE 2: Treatments for the metsulfuron-methyl pasture tolerance trials.

\begin{tabular}{llll}
\hline $\begin{array}{l}\text { Treatment } \\
\text { no. }\end{array}$ & Treatment & $\begin{array}{l}\text { Rate } \\
(\mathrm{g} \text { ai/ha) }\end{array}$ & Trade name \\
\hline 1 & untreated & - & - \\
2 & metsulfuron-methyl & 3 & Escort \\
3 & metsulfuron-methyl & 6 & $\begin{array}{l}\text { Escort } \\
\text { Escort }\end{array}$ \\
5 & metsulfuron-methyl & 12 & $\begin{array}{l}\text { Escort + Granstar } \\
5\end{array}$ \\
6 & metsulfuron-methyl + tribenuron & $3+6$ & Escort + Granstar \\
7 & metsulfuron-methyl + tribenuron & $6+12$ & Versatill \\
8 & clopyralid & 300 & Tordon 50-D \\
\hline
\end{tabular}

Pasture assessments were made on three occasions approximately 1 month apart. On each occasion, pasture composition by point analysis and herbage dry matter were determined. In addition, at 3 months after treatment, pasture composition by herbage dissection was determined. For herbage dry matter determination, 2 strips per plot were mown with either a rotary or reel mower, the clippings were weighed and total fresh weight recorded. A $200 \mathrm{~g}$ subsample was collected, oven dried, weighed and used to calculate total dry matter. Pasture composition was measured by point analysis by recording first hits of 100 points per plot using the categories, grass, clover and weeds. Herbage dissection was carried out at the final production cut by collecting a $300 \mathrm{~g}$ sample from several areas on the plot. Approximately 400 pieces $(25-40 \mathrm{~g})$ were subsampled and sorted into grasses, clovers and weeds. Green and oven dry weights for each category were recorded.

\section{RESULTS}

In the spring trials at both sites, all rates of metsulfuron-methyl significantly reduced pasture production (up to $20 \%$ at Hamilton and up to $45 \%$ at Balclutha) for the first cut except for the low rate ( $3 \mathrm{~g} / \mathrm{ha}$ ) at Hamilton (Tables 3 and 4$)$. The two higher rates (6 and $12 \mathrm{~g} / \mathrm{ha}$ ) also produced significantly less than the clopyralid and 2,4-D + picloram treatments. By the time of the second production cut, most of the treatments had recovered and their production was within $5 \%$ of the untreated controls. However, due to the variation in production at the two sites, this difference was significant for most treatments at Balclutha but not at the Hamilton location. Pasture production had recovered completely by the time of the third production cut, with some of the 
metsulfuron-methyl treatments yielding more than the untreated control plots. Dry matter production from the clopyralid and 2,4-D + picloram treatments was similar to the untreated controls for all cuts at each site.

TABLE 3: Dry matter production (kg/ha) from the Hamilton pasture tolerance trials at different harvest dates.

\begin{tabular}{|c|c|c|c|c|c|c|}
\hline $\begin{array}{l}\text { Treatment } \\
\text { no. }{ }^{1}\end{array}$ & 31.10 .97 & $\begin{array}{c}\text { Spring } \\
8.12 .97\end{array}$ & 9.1 .98 & 30.4 .98 & $\begin{array}{l}\text { Autumn } \\
5.6 .98\end{array}$ & 20.7 .98 \\
\hline 1 & 3214 & 1560 & 1959 & 805 & 423 & 813 \\
\hline 2 & 3007 & 1477 & 1918 & 177 & 196 & 807 \\
\hline 3 & 2660 & 1426 & 2223 & 196 & 197 & 755 \\
\hline 4 & 2565 & 1346 & 1995 & 127 & 88 & 515 \\
\hline 5 & 2828 & 1438 & 1850 & 204 & 229 & 787 \\
\hline 6 & 2658 & 1376 & 2334 & 157 & 115 & 580 \\
\hline 7 & 3049 & 1631 & 1990 & 474 & 533 & 1118 \\
\hline 8 & 3005 & 1664 & 2164 & 360 & 454 & 963 \\
\hline $\operatorname{LSD}(5 \%)$ & 333 & 213 & 274 & 112 & 151 & 169 \\
\hline \multicolumn{7}{|c|}{ Rainfall (mm) between dry matter cuts } \\
\hline & 45 & 107 & 52 & 25 & 110 & 370 \\
\hline
\end{tabular}

${ }^{1}$ For treatment details see Table 1.

TABLE 4: Dry matter production (kg/ha) from the Balclutha pasture tolerance trials at different harvest dates.

\begin{tabular}{|c|c|c|c|c|c|c|}
\hline $\begin{array}{l}\text { Treatment } \\
\text { no. }{ }^{1}\end{array}$ & 29.10 .97 & $\begin{array}{c}\text { Spring } \\
25.11 .97\end{array}$ & 18.12 .97 & 8.4 .98 & $\begin{array}{c}\text { Autumn } \\
7.5 .98\end{array}$ & 5.6 .98 \\
\hline 1 & 750 & 2294 & 1847 & 1470 & 467 & 327 \\
\hline 2 & 510 & 2179 & 1910 & 1495 & 380 & 291 \\
\hline 3 & 453 & 2178 & 1920 & 1565 & 365 & 291 \\
\hline 4 & 402 & 2130 & 1872 & 1532 & 339 & 272 \\
\hline 5 & 474 & 2232 & 1879 & 1493 & 358 & 283 \\
\hline 6 & 435 & 2159 & 1860 & 1529 & 365 & 269 \\
\hline 7 & 782 & 2341 & 1909 & 1469 & 410 & 316 \\
\hline 8 & 754 & 2322 & 1861 & 1545 & 427 & 368 \\
\hline $\operatorname{LSD}(5 \%)$ & 53 & 70 & 52 & 221 & 90 & 38 \\
\hline \multicolumn{7}{|c|}{ Rainfall (mm) between dry matter cuts } \\
\hline & 31 & 25 & 36 & 60 & 37 & 82 \\
\hline
\end{tabular}

${ }^{1}$ For treatment details see Table 1.

The same trends were observed in the autumn trials, although pasture recovery was slower. With these trials there are two important factors to note. Firstly there was a grass grub infestation at the Hamilton site. This was not discovered until after the treatments were applied and the metsulfuron-methyl caused severe damage to the grass plants viz, stunting, discolouration and death, which was not expected. Inspection of the site revealed a grass grub population of approximately 100 larvae $/ \mathrm{m}^{2}$. This apparently was not high enough to be noticed until the additional stress of the metsulfuron-methyl treatments was applied (Van Toor et al. 1993). It resulted in severe pasture loss in all the metsulfuron-methyl treatments for the first two production cuts. All treatments except the high rate $(12 \mathrm{~g} / \mathrm{ha})$ were producing as much as the 
untreated controls by the third production cut (Table 3 ). However, in the plots treated with metsulfuron-methyl the grasses consisted mostly of species other than perennial ryegrass, including annual summer grasses. In this trial, the clopyralid and 2,4-D + picloram treatments also significantly reduced pasture production for the first cut. This was possibly also a result of the grass grub infestation.

The second point concerns the Balclutha trial which was not grazed prior to the treatments being applied. The large bank of pasture present at the time of treatment masked the significance of any early treatment differences (Table 4) as the sulfonylurea herbicides principally affect new plant growth. The 6 and $12 \mathrm{~g} /$ ha metsulfuron-methyl treatments significantly reduced production for the second cut and the high rate was still having a significant negative effect on pasture production at the third cut.

The pasture composition results from the Hamilton spring trial (Table 5) are typical of the results from all four trials. The herbicide treatments used in these trials removed the clover plants for the duration of the trial.

TABLE 5: Point analysis and herbage dissection results from the Hamilton pasture tolerance trial conducted in spring.

\begin{tabular}{|c|c|c|c|c|c|c|c|c|}
\hline \multirow{2}{*}{$\begin{array}{l}\text { Treatment } \\
\text { No. }{ }^{1}\end{array}$} & \multicolumn{6}{|c|}{ Point analysis (\%) } & \multicolumn{2}{|c|}{$\begin{array}{c}\text { Herbage dissection (\%) } \\
9.1 .98\end{array}$} \\
\hline & grass & clover & grass & clover & grass & clover & grass & clover \\
\hline 1 & 56 & 28 & 45 & 18 & 38 & 19 & 62 & 12 \\
\hline 2 & 74 & 13 & 76 & 1 & 63 & 0 & 85 & 0 \\
\hline 3 & 65 & 17 & 71 & 1 & 77 & 0 & 84 & 0 \\
\hline 4 & 68 & 16 & 67 & 2 & 71 & 1 & 90 & 0 \\
\hline 5 & 67 & 18 & 72 & 1 & 79 & 0 & 87 & 0 \\
\hline 6 & 67 & 16 & 71 & 2 & 73 & 0 & 85 & 0 \\
\hline 7 & 79 & 3 & 80 & 0 & 77 & 0 & 82 & 0 \\
\hline 8 & 89 & 2 & 82 & 0 & 82 & 0 & 90 & 0 \\
\hline $\operatorname{LSD}(5 \%)$ & 14 & 2 & 14 & 9 & 12 & 3 & 16 & - \\
\hline
\end{tabular}

${ }^{1}$ For treatment details see Table 1 .

At Hamilton, the trial site contained many compositae weeds such as dandelion (Taraxacum officinale) and these were not well controlled by any of the treatments. The Balclutha trial site was nearly weed free.

The addition of tribenuron to the metsulfuron-methyl treatments had only minimal effect on the phytotoxicity of metsulfuron-methyl to the pasture species (Tables 3 and 4).

\section{DISCUSSION}

The results presented here are similar to those of Gomand et al. (1991) who found that metsulfuron-methyl at 5 and $10 \mathrm{~g} / \mathrm{ha}$ applied in spring, reduced pasture production by 28 and $56 \%$ respectively for the first production cut, by $18 \%$ (both rates) for the second cut and increased production by 23 and $26 \%$ respectively for the third harvest. They also reported severe damage to white clover. The level of pasture damage in these trials was considerably less that that determined by Popay et al. (1985) who measured the effects of the higher rates of metsulfuron-methyl that are required for control of scrub weeds. They found that rates of $18-38 \mathrm{~g} / \mathrm{ha}$ reduced pasture production for 9 -12 months after treatment.

In addition to the tolerance of pasture species, these trials provided additional information on the overall health of the pasture at treatment and the consequent tolerance of the pasture to metsulfuron-methyl. Our previous field observations have shown that pasture was less tolerant of metsulfuron-methyl under conditions of drought stress (unpublished data). This often resulted in more damage to pasture from autumn spraying of metsulfuron-methyl than from spring applications. In the current 
trials this again appears to be the case, with the autumn trial at Balclutha sustaining longer term damage than the spring trial did. These trials also demonstrated that other factors may influence the ability of the pasture species to tolerate metsulfuron-methyl. In the autumn trial at Hamilton where there was a grass grub infestation, metsulfuronmethyl caused significant pasture damage by killing much of the ryegrass. Although overall pasture production had recovered by the time of the third production cut, major contributors to the herbage were grasses other than ryegrass. This would impact on the persistence, quality and productivity of the pasture and reduce its ability to resist weed invasion. The presence of the grass grub was not noticed at the time of treatment as there was sufficient rainfall to maintain an apparently healthy sward despite the damage caused by grass grub to the underground parts of the plants.

Another concern revealed by these trials is the damage to clovers caused by metsulfuron-methyl. These trials showed also that the short term clover damage resulting from other products such as clopyralid and 2,4-D + picloram was as severe as that caused by metsulfuron-methyl. At the time of the third production cut, about 3 months after treatment, all the treated plots were still seriously devoid of clover. Clover is the major source of nitrogen used by other plants in pasture and it greatly improves the nutritional value of the pasture. The impact of these herbicides may have serious and long term consequences in pastoral agriculture in New Zealand.

\section{REFERENCES}

Gomand, M., Luxen, P. and Salembier, J.F., 1991. Trials for control of Rumex in permanent pasture with metsulfuron-methyl. Mededelingen-van-de-FaculteitLandbouwwetenschappen,-Rijksuniversiteit-Gent. 56: 3a:701-709.

Harrington, K.C. and Popay, A.I., 1987. Differences in susceptibility of nodding thistle populations to phenoxy herbicides. Proc. 8th Aust. Weeds Conf:: 126-129.

James, T.K., Rahman, A., Sanders, P. and Cliffe, A., 1995. Response of different nodding thistle (Carduus nutans) populations to herbicides. Proc. 48th N.Z. Plant Prot. Conf:: 252-255.

James, T.K., Rahman, A. and De Jong, P., 1997. Flazasulfuron for control of ragwort (Senecio jacobaea) in pasture. Proc. 50th N.Z. Plant Prot. Conf.: 477-481.

Martin, P., Thompson, A., Saunders, A.E. and Rahman, A., 1986. Effect of plant type on the response of ragwort to rates and times of 2,4-D application. Proc. 39th N.Z. Weed and Pest Control Conf:: 179-182.

Popay, A.I., Cornwell, M.J. and Rahman, A., 1985. Effects of metsulfuron-methyl on pasture. Proc. 38th N. Z. Weed and Pest Control Conf.: 102-105.

Rahman, A. James, T.K. and Sanders, P. 1994. Control of phenoxy herbicide resistant nodding thistle (Carduus nutans) in pasture. Proc. 47th N.Z. Plant Prot. Conf.: 68-74.

Rahman, A., James, T.K., Sanders, P. and Nicholson, K., 1993. Tolerance of perennial ryegrass/white clover pastures to five sulfonylurea herbicides. Proc. 14th Asian Pacific Weed Science Soc. Conf:: 68-74.

Van Toor, R.F., Watson, R.N., Willoughby, B.E. and Barratt, B.I.P., 1993. Evaluation of a technique for the early detection of pasture damage by grass grub, Costelytra zealandica and porina, Wiseana spp. Proc. 46th N.Z. Plant Prot. Conf.: 210-214. 